DOI: 10.20472/IAC.2018.044.034

\author{
REINHARD NECK \\ Alpen-Adria-Universität Klagenfurt, Austria \\ KLAUS WEYERSTRASS \\ Institute for Advanced Studies, Austria
}

\title{
MACROECONOMIC EFFECTS OF THE ADOPTION OF THE EURO IN SERBIA
}

\begin{abstract}
:
In 2009, Serbia applied officially for EU membership; in 2014, membership negotiations started. After joining the EU, Serbia will have to adopt the euro as legal tender as soon as it fulfils the relevant Maastricht criteria. By means of simulations with a macroeconometric model of the Serbian economy, we examine likely macroeconomic effects from Serbia's membership of the EU and the Euro Area. We show that EU accession and the introduction of the euro bring about higher real GDP, more employment, and more sustainable public finances. The benefits of joining the Euro Area are mainly due to increases in productivity.
\end{abstract}

\section{Keywords:}

Serbia; EU; Euro Area; open economy macroeconomics; econometric model

JEL Classification: E17, O52, E52 